\title{
Technical efficiency in rice ecologies of north central Nigeria: Implications for national self-sufficiency
}

\author{
O.I. Akintayo ${ }^{1}$ and M.A.Y. Rahji ${ }^{2}$ \\ ${ }^{1}$ Institute of Agricultural Research and Training, Moor Plantation, Ibadan, Nigeria \\ ${ }^{2}$ Department of Agricultural Economics, University of Ibadan, Nigeria \\ *Author for correspondence: oluremijayakint@gmail.com
}

\begin{abstract}
The quest for national self-sufficiency in rice production in Nigeria has been on for several years, with various government regimes putting different policies and programs in place in order to achieve this. A large proportion of the rice produced in Nigeria comes from the north central part, with Niger State being the second largest rice producing state in north central Nigeria. The study was carried out to examine the technical efficiency and its determinants within the rice ecologies in north central Nigeria. Through the multi-stage sampling technique, one hundred and fiftyone farmers were sampled for the study. Two mini-ecologies were identified within the lowland rice ecology in the study area, namely, River Basin Authority Catchment area (RBAC) and Non River Basin Authority Catchment area (NRBAC). Differentials in rice output were determined with the Chow test while the stochastic frontier production approach was employed to determine the technical efficiency on the individual farms. There were variations in output between the mini-ecologies, while rice output was significantly influenced by farm size, quantities of fertilisers, labour and herbicides used in rice production. Average technical efficiency measures were 70.9 and $93.6 \%$ for the identified mini-ecologies namely River Basin Authority Catchment area (RBAC) and Non River Basin Authority Catchment area (NRBAC). Variables such as extension visits and level of commercialisation had significant effects on the observed variations in technical efficiency among the rice farmers. Results indicate that there is a considerable scope for increased efficiency to meet current national rice demand.
\end{abstract}

Key words: Output differential, Stochastic frontier production

\section{Introduction}

It has been estimated that about ninety per cent of the farmed land in Nigeria is rain-fed while the most important rice production system is in the rainfed lowlands (Ugalahi et al., 2016) as it accounts for about half of the total rice production in the country (UNEP, 2005; Fashola et al., 2011). With improved water control and use of external inputs, rainfed lowland rice ecology systems may 
become more attractive and rice yields could be increased rapidly in these systems that are inherently much more stable than the upland areas (WARDA et al., 2008). Local production of rice in Nigeria is estimated at three million tonnes which has not been able to keep pace with national demand of about five million tonnes (NAMIS, 2004; NRDS, 2009; USDAERS, 2012). This deficit in national rice supply has attracted attention from several successive Nigerian governments leading to various interventions in the rice subsector of the economy (Orefi, 2011; Onyenekwe and Okorji, 2015). These interventions include the establishment of the River Basin Development Authority (RBDA) in 1976 to harness the country's water resources and optimise the country's agricultural resources for food self-sufficiency (Akanmu et al., 2007). The river basins were expected to contribute positively to the nation's search for food security by reducing the country's dependence on rain-fed agriculture and increase the proportion of irrigated agriculture that would make possible two, and sometimes three cropping seasons in one year (Akanmu et al., 2007; Shariff, 2009).

The Green Revolution launched in 1980 aimed at increasing food production and raw materials in order to ensure food security and self-sufficiency in basic staples which included rice. The National Special Programme on Food Security (NSPFS) was launched in 2002 with objectives which included assisting farmers to increase their output, productivity and their capacity for effective utilisation of resources for selfsufficiency. The Agriculture Transformation Action Plan (ATAP) which was launched in 2011 focuses on developing the value chain of specific commodities which include rice, cocoa, cotton, cassava and sorghum. In spite of all these interventions, the smallholder rainfed rice farmer in Nigeria produces 4.6 tonnes of paddy per year from an annual crop area of 3.3 hectares (Ogundele and Okoruwa, 2006; Idiong, 2007). The average national yield of rice in 2012 was 1.8 tonnes of paddy per hectare (FAO, 2013), which is quite low when compared with the national average potential of 3.0 $\mathrm{t} \mathrm{ha}^{-1}$ for upland system and $5.0 \mathrm{t} \mathrm{ha}^{-1}$ for lowland system (Imolehin and Wada, 2005). The consequence of this is that local rice production has not been able to meet up with the domestic demand and as a result, the importation of rice has become necessary to bridge the demand-supply gap (Bamidele et al., 2010; Johnson et al, 2013).

Strategies for sustainable increased production are necessary for the country to become self-sufficient in rice production. These would be better built on an improved production environment with a focus on efficiency at the farm level. Efficiency refers to the minimum resource level that is theoretically required to run the desired operation in a given system (Tangen, 2006). It is measured as the ratio of output produced with given inputs relative to the maximum feasible output. A proper understanding of the performance of the rice sector and the factors affecting such performance is vital. Such understanding is expected to give room for specific policies, decisions and actions to address particular factors/ situations at the farm level to bring about positive change towards the attainment of national self-sufficiency. It is therefore important to examine the factors that would contribute greatly to improving rice output in Nigeria so as to pave the way for sustainable increased production and 
eventually self-sufficiency of the staple crop (Ogundari et al., 2012). Selfsufficiency has been defined as the ability to meet consumption needs (particularly for staple foods) from own production rather than importing (Minot and Pelijor, 2010).

\section{Methodology}

\section{The study area}

The study was carried out in Niger state which is situated in the North-Central geopolitical zone and guinea savannah agroecological zone of Nigeria. It is situated between latitudes $8^{\circ} 20$ and $11^{\circ} 30$ north and longitude $3^{\circ} 80$ and $7^{\circ} 20$ east. Major crops cultivated in Niger state include rice, yams, sorghum, maize, groundnuts, sugarcane, melon and millet. Niger state is one of the three major rice producing states (Niger, Kaduna and Taraba) in north central Nigeria and one of the states with the largest rice land area of between 184,000 and 230,000 hectares.

\section{Sampling procedure}

The multi-stage sampling technique was employed for the study. This involved the random selection of two out of the three Agricultural Development Programme (ADP) zones in the State, the selection of Local Government Areas (LGAs) from the two selected ADP zones (zones I and III), the selection of villages from the LGAs and the selection of rice farmers

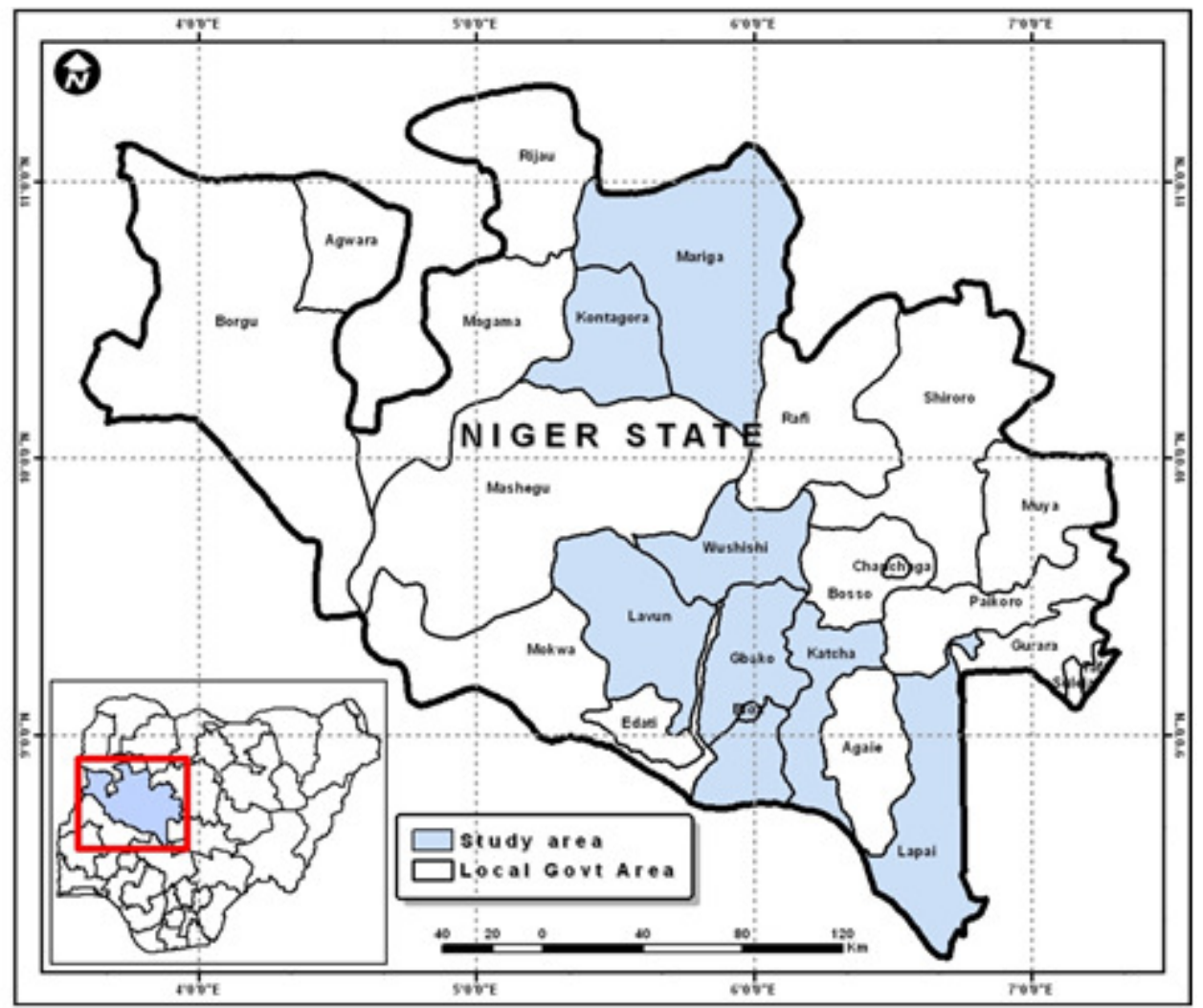

Figure 1. Study area. 
from the selected villages. A total of one hundred and fifty-one rice farmers was randomly selected from fourteen villages in seven LGAs. The lowland rice production system in the study area was divided into two major mini-ecologies based on location of the rice farms. These are rice farms located in the River Basin Authority Catchment areas (RBAC) and rice farms located outside these catchment areas, that is, Non River Basin Authority Catchment areas (NRBAC). River Basin Development Authorities were created to help reduce the country's dependence on rain-fed agriculture and increase the proportion of irrigated agriculture that would make possible two or more cropping seasons in a year (Akanmu et al., 2007; Shariff, 2009). River basin catchment areas in this study refer to locations around the river basin which are expected to benefit directly in the use of agricultural water through irrigation facilities from river basin authority. Thus, out of the 151 sampled lowland rice farmers, 78 were categorised into the NRBAC group and 73 into RBAC group.

\section{Data collection}

Primary data were collected using a pretested structured questionnaire, copies of which were administered to the selected rice farmers via interview schedules. Data were collected on farm and farmers' characteristics, as well as on details of rice production.

\section{Methods of data analyses}

Chow test was used to determine the output differentials, while the method used to determine technical efficiency is the parametric approach, using the stochastic frontier model based on the estimation of the frontier production function.
The stochastic frontier production function is expressed as:

$$
\begin{aligned}
& \mathrm{Y}_{\mathrm{i}}=f\left(\mathrm{x}_{\mathrm{i}} ; \beta\right) \exp \left(\mathrm{V}_{\mathrm{i}}-\mathrm{U}_{\mathrm{i}}\right) \quad \mathrm{i}=1,2, \\
& \text {......, } N \text {.............................. Eq. (1) }
\end{aligned}
$$

Where:

$Y_{i}=$ Quantity of output

$\mathrm{X}_{\mathrm{i}}=$ vector of input quantities

$\beta=$ vector of parameters

$\mathrm{V}_{\mathrm{i}}$ is a random error assumed to be independently and identically distributed with zero mean which is associated with random factors such as measurement errors in production and weather which are out of the control of the firm/farmer. Ui represents non-negative random variables which are assumed to account for technical inefficiency in production (Coelli, 1996).

This stochastic frontier model was proposed by Meeusen and Van den Broeck (1977) and Aigner et al. (1977). Technical efficiency of a firm $i$ is taken to be;

$\mathrm{TE}_{\mathrm{i}}=\exp \left(-\mathrm{U}_{\mathrm{i}}\right)$

so that $0 \mathrm{~d}<\mathrm{TE}<1$

That is,

$\mathrm{TE}_{\mathrm{i}}=\mathrm{Y}_{\mathrm{i}} / \mathrm{Y}_{\mathrm{i}}^{*}$

(output of ith farm relative to the output that could be produced by a fully efficient farm using the same input bundle. That is, observed farm output relative to the corresponding frontier output, given the available technology).

The frontier production function has been widely applied in empirical studies using farm-level data in developed and 
developing countries. These include Kalirajan (1982), Bagi (1982), Oladeebo and Fajuyigbe (2007), and Masunda and Chiweshe (2015).

Parameters of the stochastic production function were estimated by the maximum likelihood method using Frontier 4.1 Software Version (Coelli, 1996).

\section{Model specification}

The empirical model employed in the stochastic production frontier is the CobbDouglas functional form specified as:

$$
\mathrm{Ln} \mathrm{Q}=\beta_{0}+\beta_{1} \ln \mathrm{X}_{1}+\beta_{2} \ln \mathrm{X}_{2}+\beta_{3} \ln \mathrm{X}_{3}+
$$
$\beta_{4} \ln X_{4}+$ vi - ui ....................... Eq. (4)

That is,

$\operatorname{Ln} \mathrm{Y}=\beta_{0}+\Sigma \mathrm{b}_{\mathrm{i}} \ln \mathrm{X}_{\mathrm{i}}+\mathrm{vi}-\mathrm{ui}$

Where:

$\mathrm{Ln}=$ natural $\log$

$\mathrm{Q}=$ rice output in $\mathrm{kg}$; and

$\mathrm{X}_{\mathrm{i}}=$ factor inputs in rice production

Where:

i $=1,2, \longrightarrow, 5$;

$\mathrm{X}_{1}=$ fertiliser $\left(\mathrm{kg} \mathrm{ha}^{-1}\right)$;

$\mathrm{X}_{2}=$ Labour (mandays ha ${ }^{-1}$ );

$\mathrm{X}_{3}=$ Herbicide $\left(\right.$ litre ha ${ }^{-1}$ );

$\mathrm{X}_{4}=$ rice seeds planted $\left(\mathrm{kg} \mathrm{ha}^{-1}\right)$;

$\mathrm{B}_{0,} \mathrm{~b}_{\mathrm{i}}=$ parameters to be estimated;

$\mathrm{b}_{\mathrm{i}} \quad=$ logarithm coefficient of independent variables;

$\mathrm{v}_{\mathrm{i}} \mathrm{s}$ are assumed to be independent and identically distributed normal random errors having mean zero and variance $\sigma_{\mathrm{v}}{ }^{2}$ and are also distributed independently of $\mathrm{u}_{\mathrm{i}}$; and

$u_{i} s$ are non-negative technical inefficiency effects representing management factors and are assumed to be independently distributed with mean $\mu_{\mathrm{i}}$ and variance $\sigma^{2}$ (Battasse et al., 1996; Munir et al., 2002) The technical inefficiency model however, is specified as:

$\mu_{1}=\delta_{0}+\delta_{1} Z_{1}+\delta_{2} Z_{2}+\delta_{3} Z_{3}+\delta_{4} Z_{4}+$ $\delta_{5} Z_{5}+\delta_{6} Z_{6}$ Eq. (6)

Where:

$\mu_{1}$ is technical inefficiency term;

$\mathrm{Z}_{1}=$ educational level of farmer;

$\mathrm{Z}_{2}=$ rice farming experience;

$\mathrm{Z}_{3}=$ farm to market distance;

$\mathrm{Z}_{4}=$ extension visits;

$\mathrm{Z}_{5}=$ proportion of total land cultivated to rice;

$\mathrm{Z}_{6}=$ commercialisation level; and

$\delta_{\mathrm{i}}$ are parameters to be estimated.

The variables used in the Cobb Douglas functional form and in the inefficiency model are described in Table 1.

\section{Chow test (Test for output differentials)}

Chow test is a test for structural change; an econometric test to determine whether the coefficients/parameters in a regression model are the same in separate subsamples. The standard $\mathrm{F}$ test for the equality of two sets of coefficients in linear regression models is called a Chow test. This test was used to test for the equality of production function parameters of the two production systems. This is to determine whether there are significant differences in the production parameters of the two mini-ecologies. 
Variables

Description

Fertilisers

Labour

Herbicides

Rice seeds

Educational level

Rice farming experience

Farm to market distance

Extension visits

Proportion of total land cultivated to rice
Quantity of chemical fertilizers applied to farmers' rice plots

This is the product of the number of people employed and the total time worked, in hours, by each individual on the rice plot. All labour inputs (hired and family labour) involved in the production process (land preparation all through to winnowing) were incorporated and converted to man-day equivalent.

Quantity of weed-control chemicals applied to farmers' rice plots

These are the planting materials from which rice paddy is obtained

Number of years of schooling completed by the farmers

This is how long the farmers have been involved in rice cultivation

This is the distance between rice farm and place of output sale

Number of interactive visits by an agricultural extension worker to a farmer in order to give advisory services and/or practical demonstrations with regards to the promotion of better rice production.

This is the proportion of farmer's total farmland that is cultivated to rice

This is the proportion of total rice produced that is sold
Unit of measurement

Kilogram hectare ${ }^{-1}$

Man-days hectare ${ }^{-1}$

Litre hectare ${ }^{-1}$

Kilogram hectare

Number of years

Number of years

Kilometers

Proportion

Proportion 
For RBAC production system,

$\mathrm{Q}=\mathrm{f}\left(\mathrm{X}_{1}, \mathrm{X}_{2}, \mathrm{X}_{3},-\mathrm{X}_{\mathrm{n}}\right)$

sample size $=\mathrm{N}_{1}$...................... Eq. (7)

For NRBAC production system,

$\mathrm{Q}=\mathrm{f}\left(\mathrm{X}_{1}, \mathrm{X}_{2}, \mathrm{X}_{3},-\mathrm{X}_{\mathrm{n}}\right)$

sample size $=\mathrm{N}_{2}$

The two samples were combined to estimate a third production function given as:

$\mathrm{Q}=\mathrm{f}\left(\mathrm{X}_{1}, \mathrm{X}_{2}, \mathrm{X}_{3},-\mathrm{X}_{\mathrm{n}}\right)$

sample size $=\mathrm{N}_{1}+\mathrm{N}_{2} \quad$ ……...... Eq. (9)

Thus, Equation (9) represents the two systems combined.

Following Onyenwaku (1997) and Olomola (1998), Chow's F-statistic computed from the estimated Equations 7,8 and 9 is given as:

$$
\frac{\left[\Sigma e_{3}^{2}-\sum e_{1}^{2}-\sum e_{2}^{2}\right] / \mathrm{K}_{3}-\mathrm{K}_{1}-\mathrm{K}_{2}}{\left[\Sigma e_{1}^{2}+\Sigma e_{2}^{2}\right] / \mathrm{K}_{1}+\mathrm{K}_{2}}
$$

Eq. (10)

Where:

$\sum e_{1}^{2}, \sum e_{2}^{2}, \sum e_{3}^{2}$ are error sum of squares for Equations 7,8 and 9 respectively

$\mathrm{K}_{1}, \mathrm{~K}_{2}$ and $\mathrm{K}_{3}$ are degrees of freedom for Equations 7,8 and 9 respectively.

If $\mathrm{F}$ calculated is greater than tabulated $\mathrm{F}$, there is significant difference in production parameters between the two groups. However, if $\mathrm{F}$ calculated is less that tabulated $F$, there is no significant difference in production parameters of the two groups. That is, the production parameters are equal and there are no structural differences between the two systems. Therefore, if the $F$ statistic exceeds the critical $F$, we reject the null hypothesis that the two regressions are equal.

\section{Results and discussion}

\section{Socio-demographic characteristics of respondents}

Majority (over 90\%) of the farmers were male, indicating that rice farming in the study area is male-dominated. The average age of rice farmers under RBAC and NRBAC were 42.48 and 47.95 years respectively (Table 2). This implies that the rice farmers are within active productive age range, and can therefore still farm actively for several more years. With regard to the number of years of formal education obtained by the farmers, those under RBAC had an average of 3.51 years while those under NRBAC had an average of 4.68 years of schooling.

All the farmers had been growing rice for an average of 22.8 years. These farmers are therefore not new entrants into the business of rice farming, but can be referred to as experienced rice farmers. Average distance travelled between home and rice farm by the farmers was $2.41 \mathrm{~km}$ and $2.26 \mathrm{~km}$ in NRBAC and RBAC respectively. The average farm size cultivated to rice was 2.47 hectares in NRBAC and 3.05 in RBAC. The minimum proportion of rice produced that is sold (commercialization level) in both mini-ecologies is $58.3 \%$ while the maximum is $95.0 \%$. However, the average level of commercialization in NRBAC and RBAC was $80 \%$ and $82 \%$ respectively. This implies that rice production by these farmers is mainly commercial. The importance of 
Table 2. Socio-demographic characteristics of respondents

\begin{tabular}{lrr}
\hline Characteristics & \multicolumn{2}{c}{ Sample mean } \\
\cline { 2 - 3 } & NRBAC & RBAC \\
\hline Age (years) & 47.95 & 42.48 \\
Formal education (years) & 4.68 & 3.51 \\
Sex & 98.72 & \\
Male & 1.28 & 91.79 \\
Female & 11.85 & 8.21 \\
Household size & 22.59 & 11.13 \\
Experience in rice farming (years) & 2.47 & 21.40 \\
Size of rice farm (hectares) & 2.41 & 2.05 \\
Distance between farm and homestead (km) & 2.26 \\
Number of extension visits received per year & 13.33 & 11.29 \\
Commercialisation level (\%) & 80 & 82 \\
\hline
\end{tabular}

agricultural extension services in agricultural development can not be overemphasised. Visits by extension workers to farmers are vital to farm productivity. The numbers of such visits received by the respondents are shown in Table 2.

Estimation of Cobb Douglas production function model parameters is given in Table 3. For RBAC rice farms, inputs which significantly influence rice output positively were size of rice farm, fertilisers, agrochemicals and labour. Inputs which significantly and positively influenced rice output in NRBAC rice farms on the other hand are farm size, seeds and labour. This implies that increase in the quantities of these inputs used would bring about increase in quantity of rice produced.

Chow test result from Equations 7, 8, 9 and 10 for output differential using parameters from Table 1 gave an $\mathrm{F}$ calculated value of 7.2151 with corresponding tabulated $\mathrm{F}$ values of 2.321 and 1.8307 at 1 and $5 \%$ respectively. Since $\mathrm{F}_{\mathrm{cal}} \tilde{\mathrm{A}} \mathrm{F}_{\mathrm{tab}}$, the null hypothesis is rejected. Thus, there are significant differences in output levels between the two miniecology production systems.

A t-test was carried out to confirm the output differential magnitude between the two mini-ecologies.

$\begin{array}{ll}\text { NRBAC } & 2.46 \mathrm{tha}^{-1} \\ \text { RBAC } & 1.53 \mathrm{tha}^{-1} \\ \text { Difference } & 0.94 \mathrm{tha}^{-1} \\ \text { t-stat } & 7.41 * * * \\ & \\ \text { (*** significant at } 1 \%) & \end{array}$

The quantitative results shown in this study confirms the qualitative results of Johnson et al. (2013), who reported the existence of wide variations in the intensity of production, use of modern inputs and water control in lowland rice system in Nigeria.

\section{Technical efficiency model results}

The estimated gamma parameter (Ò) of the inefficiency model indicates that about ninety-nine per cent $(99.92 \%)$ and fiftyfive per cent $(55.51 \%)$ of the variation in 
Table 3. Parameter estimates of Cobb Douglas production function model for lowland miniecologies

\begin{tabular}{|c|c|c|c|c|c|c|}
\hline \multirow[t]{2}{*}{ Variable } & \multicolumn{2}{|c|}{ NRBAC } & \multicolumn{2}{|c|}{ RBAC } & \multicolumn{2}{|c|}{ Pooled } \\
\hline & Coefficient & t-stat & Coefficient & t-stat & Coefficient & t-stat \\
\hline $\operatorname{lnFmsz}$ & $\begin{array}{c}0.5222 \\
(0.0533)\end{array}$ & $9.79 * * *$ & $\begin{array}{c}0.9922 \\
(0.4015)\end{array}$ & $2.47 * *$ & $\begin{array}{l}0.3486 \\
(0646)\end{array}$ & $5.40 * * *$ \\
\hline $\operatorname{lnSd}$ & $\begin{array}{c}0.2768 \\
(0.0005)\end{array}$ & $6.66^{* * *}$ & $\begin{array}{l}-0.1461 \\
(0.1626)\end{array}$ & -0.90 & $\begin{array}{c}0.1989 \\
(0.0263)\end{array}$ & $7.56 * * *$ \\
\hline $\operatorname{lnFert}$ & $\begin{array}{c}0.0067 \\
(0.0110)\end{array}$ & 0.61 & $\begin{array}{l}-0.8936 \\
(0.0116)\end{array}$ & $-2.12 * *$ & $\begin{array}{c}0.0076 \\
(0.0116)\end{array}$ & 0.66 \\
\hline $\operatorname{lnHerb}$ & $\begin{array}{c}0.0113 \\
(0.0094)\end{array}$ & 1.20 & $\begin{array}{c}1.3279 \\
(0.3314)\end{array}$ & $4.01 * * *$ & $\begin{array}{l}-0.0009 \\
(0.0087)\end{array}$ & -0.11 \\
\hline $\operatorname{lnLab}$ & $\begin{array}{l}-0.0217 \\
(0.2831)\end{array}$ & -0.08 & $\begin{array}{c}0.8351 \\
(0.1813)\end{array}$ & $4.61 * * *$ & $\begin{array}{c}0.8719 \\
(0.0777)\end{array}$ & $11.22 * * *$ \\
\hline Const & 6.5437 & 6.04 & 7.7197 & 3.39 & 2.9452 & 9.19 \\
\hline $\mathrm{R}^{2}$ & 0.8912 & & 0.8589 & & 0.8404 & \\
\hline
\end{tabular}

*Significant at $10 \%$ level; **Significant at $5 \%$ level; ***significant at $1 \%$ level; Figures in parentheses $=$ standard errors

$\mathrm{Ln}=$ natural logarithm; Fmsz = farm size; $\mathrm{Sd}=$ rice seed $;$ Fert $=$ fertilizers; Herb = herbicides; $\mathrm{Lab}=$ labour

rice output within the RBAC and NRBAC groups respectively, was due to differences in their technical efficiencies. The Technical Efficiency (TE) score distribution was between 0.317 and 0.994 , with a mean of 0.709 for RBAC group; while that for the NRBAC group was between 0.100 and 0.992 with a mean of 0.936 .

About eighteen per cent (17.95\%) of the rice farms in RBAC areas operated at a technical efficiency level of between 0.10 and 0.50 ; while only $6.85 \%$ of the farms in NRBAC areas operated at the same level. Thus, $82.05 \%$ of farms in
RBAC areas and $93.15 \%$ of farms in NRBAC areas operated at technical efficiency levels above 0.50. However, $50.00 \%$ of farms in RBAC and $82.19 \%$ of farms in NRBAC areas operated at technical efficiency levels above 0.75 .

Although rice farms in the RBAC category are expected naturally to have higher technical efficiency by virtue of their location in the river basin area and potential benefits of their location, this was not the case. There is, therefore, considerable scope for efficiency improvements towards greater output that would lead to increased farm incomes and 
promote self- sufficiency in rice production for the nation.

The estimated maximum likelihood parameters of the production function frontier with inefficiency model indicate that the variables (farming experience, extension visits and commercialisation level) had negative and significant effects on inefficiency levels for rice farms in the RBAC group. However, for rice farms in the NRBAC group, only two variables (extension visits and commercialisation level) had negative and significant effects on inefficiency levels. This highlights the importance of the role of extension workers in farmers' productivity and efficiency. The more interactions the rice farmers have with extension workers, the higher their technical efficiency would be for increased output. In addition, the more market-oriented the rice farmers are (higher commercialisation level), the lower their technical inefficiency. According to Bravo-Ureta and Pinheiro (1997), the shortfalls in efficiency however indicates that there can be increase in output without new technology and without the use of additional conventional inputs

\section{Conclusion}

Results from the study indicate significant differentials in output quantities between the mini-ecologies of the lowland rice production system in the study area. Factors which positively and significantly influence rice output include farm size, seed, fertilisers, herbicides and labour. However, there is considerable scope for increased rice production in the study area through improvements in technical efficiency especially in the RBAC areas. Since the RBAC areas are expected to benefit directly in the use of agricultural water from river basin authority through irrigation facilities, it is important that efforts by appropriate authorities be directed towards revitalising the nonfunctional irrigation facilities for better production in the RBAC areas in order to pave the way for sustainable increased rice production in the mini-ecology. For both mini-ecologies, higher frequency of contacts with extension workers by rice farmers will contribute significantly to increased efficiency. This would be the result when extension workers communicate appropriate technologies to farmers and follow-up such technologies through proper monitoring of farmers' activities to ensure desired outcome. This implies that there is need for a very vibrant national agricultural extension system for farmers to be able to contribute effectively towards national self-sufficiency in rice production. Commercialization level also had significant influence on the technical efficiency. In other words, the more market-oriented the rice farmers are, the more technically efficient they would be in producing more rice.

\section{References}

Aigner, D.J., Lovell, C.A.K. and P. Schmidt, P. 1977. Formulation and estimation of stochastic Frontier production function models. Journal of Econometrics 6:21-37.

Akanmu, J.O, Eluwa, O. and Ekpo, I. 2007. Chronicles of River Basin Management in Nigeria. ProceedingS of Intenational congress on River basin Management 22-24 March, Antalya Turkey. pp. 106-114.

Bagi, F.S. 1982. Relationship between farm size and technical efficiency in west Tennessee agriculture. South Journal of Agricultural Economics 14:139-144. 
Bamidele, F.S., Abayomi, O.O and Esther, O.A. 2010. Economic analysis of rice consumption patterns in Nigeria. Journal of Agricultural Science and Technology 12:1-11.

Battese, G. E., Malik, S.J. and Gill, M.A. 1996. An investigation of technical inefficiencies of production of wheat Farmers in four districts of Pakistan. Journal of Agricultural Economics 47:37-49.

Bravo-Ureta, B.E and Pinheiro, A.E. 1997. Technical, economic and allocative efficiency in peasant farming: Evidence from the Dominican Republic. The developing economies XXXV-I:48-67.

Coelli, T.J. 1996. A guide to Frontier version 4.1: A computer program for stochastic frontier production and cost function estimation. CEPA working paper 7/96, Department of Econometrics, university of New England, Armidale, Australia.

FAO. 2013. FAOSTAT Accessed September 14, 2013 from www.faostat.org

Fashola, O.O., Olaniyan, G.O. Aliyu, J and Wakatsuki, T. 2011. Water management practices for sustainable rice production in Nigeria. Accessed April 27, 2011 from www.kinkiecotech.jp/download/

Idiong, I.C. 2007. Estimation of farm level technical efficiency in small scale swamp rice production in Cross River state of Nigeria: A stochastic frontier approach. World Journal of Agricultural Sciences 3(5):653-658.

Imolehin, E.D and Wada, A.C. 2005. Meeting the rice production and consumption demands of Nigeria with improved technologies. International Rice Commission Newsletter vol 49.FAO, Rome, Italy.
Johnson, M., Takeshima, H. and GymahBrempong, K. 2013. Assessing the potential and policy alternatives for achieving rice competitiveness and growth in Nigeria. IFPRI discussion paper 01301. International Food Policy Research Institute, Washington D.C., USA.

Kalirajan, K. 1982.On measuring yield potential of the high yielding varieties technology at farm level. Journal of Agricultural Economics 33:227-236.

Masunda, S. and Chiweshe, R.A. (2015) A stochastic frontier analysis on farm level technical efficiency in Zimbabwe: A case of Marirangwe smallholder dairy farmers. Journal of Development and Agricultural Economics 7(6):237-242

Meeusen, W. and Van den Broeck. 1977. Efficiency estimation from CobbDouglas production functions with composed error. International Economic Review 18:435-444.

Minot, N. and Pelijor, N. 2010. Food security and food self sufficiency in Bhutan. Washington, D.C. International Food Policy Research Institute (IFPRI) and Ministry of Agriculture and Forests (MoAF). http:/ /ebrary.ifpri.org/cdm/ref/collection/ p15738coll2/id/

Munir, A., Ghulam, M.C. and Mohammad, I. 2002. Wheat productivity, efficiency and sustainability: A stochastic production frontier analysis. The Pakistan Development Review 41.4 Part II:643-663.

NAMIS. 2004. Nigeria Agri Marketing News Bulletin No.4 www.afmin.net Accessed 3/9/2004.

NRDS. 2009. Federal republic of Nigeria. Paper prepared for the coalition for African rice development (CARD), Tokyo, Japan June 2009. www.jica.go. 
L p / a c tivities/issues/ agricul.pdf271009.pdf Accessed 11/10/ 2009.

Ogundari, K., Amos, T.T. and Okoruwa, V.O. 2012. A review of Nigerian agricultural efficiency literature, 19992011: What does one learn from frontier studies?. African Development Review 24 (1): 93-106

Ogundele, O.O. and Okoruwa, V.O. 2006. Technical efficiency differentials in rice production technologies in Nigeria. AERC Research Paper 154. African Economic Research Consortium, Nairobi, Kenya.

Oladeebo, J.O and Fajuyigbe, A.A. 2007. Technical efficiency of men and women upland rice farmers in Osun state, Nigeria. Journal of Human Ecology 22(2):93-100.

Olomola, A.S. 1998. Choice and productivity effects of animal traction technology in the semi-arid zone of northern Nigeria. Issues in African Rural Development Monograph series no. 12. Winrock international, USA.

Onyenekwe, S.C and Okorji, E.C. 2015. Effects of off-farm work on the technical efficiency of rice farmers in Enugu state, Nigeria.Journal of Agricultural Economics and Development 4(4):44-50.

Onyenwaku, C.E. 1997. Impact of technological change on output, income, employment And factor shares in rice production in southwestern Nigeria.
Issues in African Rural Development Monograph Series No. 5. Winrock International, USA.

Orefi, A. 2011. Fertilizer usage and technical efficiency of rice farms under tropical conditions: A Data Envelopment Analysis (DEA). Journal of Agricultural Science 2(2):83-87.

Shariff, U. 2009. Nigeria: Politics of river basins authorities. www.dailytrust. daily trust.com/index.php. Accessed 12/5/2011.

Tangen, S. 2006. Understanding the Concept of Productivity. www.aipa. org.

Ugalahi, U.B., Adeoye, S.O and Agbonlahor, M.U. 2016. Irrigation potentials and rice self-sufficiency in Nigeria: A review. African Journal of Agricultural Research 11(5):298-309.

UNEP. 2005. Integrated assessment of the impact of trade liberalization: A country study on the Nigerian rice sector. 107pp. United Nations Environment Programme. Accessed February 16, 2009 from www.unep. org

USDA-ERS (United States Department of Agriculture Economic Research Service) 2012. International baseline data. Accessed February 20, 2013 from www.ers.usda.gov

WARDA, FAO and SAA. 2008. NERICA: The New Rice for AfricaA compendium. www.warda.org Accessed 17/1/2011. 